\title{
The Language of Persuasion in Courtroom Discourse: A Computer-Aided Text Analysis
}

\author{
Bader Nasser Aldosari ${ }^{1 *}$ \\ Department of Law, College of Science and Humanities \\ Prince Sattam bin Abdulaziz University \\ Saudi Arabia
}

\author{
Ayman F. Khafaga ${ }^{2}$ \\ Department of English, College of Science and Humanities \\ Prince Sattam bin Abdulaziz University, Saudi Arabia \\ Department of English, Faculty of Arts and Humanities \\ Suez Canal University, Egypt
}

\begin{abstract}
This paper uses a Computer-Aided Text Analysis (CATA) and a Critical Discourse Analysis (CDA) to investigate the language of persuasion in courtroom discourse. More specifically, the paper tries to explore the extent to which a computer-aided text analysis contributes to decoding the various persuasive strategies employed to control, defend or accuse within the framework of courtroom discourse. Two research questions are tackled in this paper: first, what are the strategies of persuasion employed in the selected data? Second, how can a computer-aided text analysis reveal these persuasive tools that influence the attitudes of recipients? By means of the adopted computer-assisted textual analysis, four CDA strategies are discussed in this study: questioning, repetition, emotive language, and justification. The paper reveals that language in courtroom discourse can be used to persuade or biased to manipulate. In both cases, a triadic relationship between language, law, and computer is emphasized.
\end{abstract}

Keywords-Computer-aided text analysis; legal discourse; persuasion; critical discourse analysis; power; control

\section{INTRODUCTION}

Within the framework of legal settings, language is a powerful tool for persuasion. Linguistic expressions are widely employed in court to defend or to accuse. Language is perceived as a tool that reflects social control and power [1]. This sociolinguistic characteristic is not only noticeable in social settings, but also in legal settings [2]. In courtrooms, language is used and/or abused to facilitate control and to exercise power among discourse participants, be they lawyers, judges, witnesses, or otherwise. This is because a trial is a linguistic activity in which a linguistic interaction is meant by language users to advocate their position and to challenge their opponents. Language in this sense is perceived as a tool of control. Thus, one can say that there is a reciprocal relationship between language and legal discourse; reciprocal in the sense that the latter is interpreted according to the linguistic interpretation of the former in discourse. From this context, the relationship between language and law can be said to be worthy of linguistic research. This relationship is analytically accentuated by the application of a computeraided text analysis in order to explore the ways through which language is used within the framework of courtroom discourse. This article, therefore, attempts to present a corpus linguistic analysis of Moussaoui's trial in 2006, by using critical discourse analysis approach through discussing certain

Paper Submission Date: June 29, 2020

Acceptance Notification Date: July 15, 2020

*Corresponding Author persuasive devices used in the opening statements of the defense attorney and the U.S. government attorney in such a case. Here, the focus is on the persuasive power of language; that is, how it is persuasively used in such a type of discourse (i.e. legal discourse) to influence the attitudinal behavior of recipients.

\section{A. Objectives of the Study}

This study tries to achieve the following objectives:

1) To shed light on the analytical relevance of applying a computer-aided text analysis to the investigation of legal language.

2) To explore the different persuasion tactics used in courtroom discourse.

3) To demonstrate the extent to which persuasive tools facilitate control and influence attitudes among legal discourse participants.

4) To highlight the triadic relationship between language, law, and computer in terms of discourse interpretation, and within written legal discourse.

5) To reflect on the way courtroom discourse serves as a tool of institutional empowerment and control.

\section{B. Research Questions}

Two main research questions this study attempts to answer:

1) What are the strategies of persuasion employed in the selected data?

2) How can a computer-aided text analysis reveal these persuasive tools?

\section{Significance of the Study}

The significance of this paper lies in its attempt to offer a corpus linguistic analysis that functions to reveal hidden strategies of persuasion beyond the mere legal and linguistic expressions in courtroom interaction. This is conducted by virtue of a computer-aided text analysis of the corpus under investigation. As such, the paper tries to shed light on the possibility and the relevance of applying computer software programs to the linguistic and discursive analysis of texts. Crucially, using computer software to reveal hidden persuasive strategies, the core concern of this paper, aims to offer better understanding of the way language is used and/or 
abused to achieve the goals of its users within different legal settings. This linguistic analysis attempts to offer insights into the understanding of the different uses of language to produce persuasion in legal discourse, which also aims to emphasize the relationship between language, law, and computer. The study, therefore, provides some sort of computational linguistic enlightenment to the ways through which language is used or abused in legal settings.

The remainder of this paper is structured as follows. Section 2 presents some theoretical preliminaries and reviews the literature relevant to the topic under investigation. Section 3 provides the methodology of the study. Section 4 is the analysis of the selected data. Section 5 offers the conclusion of the article and recommends further studies for future research.

\section{LITERATURE REVIEW}

\section{A. Computer-Aided Text Analysis}

A Computer-Aided Text Analysis (henceforth, CATA) provides the possibility of performing content analysis on a large amount of data. This computer-based software helps researchers and text analysts arrive at specific indicators that play a part in the interpretation of texts within the framework of corpus linguistics [3]. CATA can be used to identify the linguistic significance of words, either individual words or words in company; that is, words in their contextual occurrence in text $[4,5]$.

Content analysis is one of the options achieved by CATA. According to Weber [6], content analysis is a systematic, replicable approach for compressing words of a text into content categories that are based on explicit rules of coding. In so doing, this type of analysis can help in classifying data into categories by focusing on the semantic of words that can be put together to form a larger class of a particular content (theme). As such, CATA can be applied to different types of texts, including courtroom discourse, particularly opening statements delivered in these settings, the main concern of this study.

Frequency Distribution Analysis (FDA) is another variable addressed by CATA. This option is based on the assumption that specific words are selected from the text under investigation to undergo a frequency analysis [7]. This type of analysis functions to arrive at the number of occurrences a selected word has in text, which, in turn, helps text analysts derive their linguistic results, either discursively or otherwise.

A KeyWord in Context (KWIC) is a further analytical option that can be targeted by CATA [8]. This analytical dimension reveals the contextual environment in which a specific word or phrase is used in text. This also sheds light on the linguistic significance of certain words. Significantly, both frequency distribution analysis and keyword in context can be realized by Concordance, which is also available within CATA framework. According to [9] and [10], concordance is a computer software program through which large amount of data can be collected, accessed, classified, and analyzed to arrive at particular results contributive to corpus linguistics of texts. Thus, the use of concordance offers some sort of analytical extension that can retrieve all occurrences, as well as all keyword contexts occurred in a corpus [11, 12].

\section{B. Legal Discourse Studies}

The language of legal discourse has attracted many scholars, including legal experts, philosophers, linguists and other practitioners of this genre. These scholars from different disciplines provide much literature addressing legal discourse from different perspectives: by discussing the relationship between language and law via shedding light on the different linguistic aspects operating in legal texts $[13,14]$; by decoding the lexico-grammatical features of the legal texts [15]; by exploring power relations between participants in courtrooms contexts $[16,17]$; by focusing on the influence of language in the interpretation of legal discourse [18]; by offering new insights into the relevant social role of language to legal discourse within legal communities, with the intention to discuss concepts related to identities and culture [19, 20, 21, $22,23]$. The main focus of these studies revolves around the role of language in producing, reproducing, or legitimizing power relations within the framework of legal discourse. They describe the way through which law, with its actors inside the arena of legal discourse practices, conceives the relationship between discourse, power and ideology.

Further insights have also been offered to the manner through which language is skillfully employed within legal communities to negotiate issues of justice [24]; and the way aspects of language are practiced and negotiated by legal discourse practitioners [25]. Other studies have tackled other topics in courtroom discourse from different perspectives. Among these studies is [26] whose contribution in legal discourse focuses on the analysis of legal language in written contracts. They shed light on the linguistic devices used in writing contracts such as the use of modality for obligation. Other contributions concentrate on aspects of power, control, gender, discrimination, and dominance in the courtroom [27, 28]. From this context, it can be noticed that legal discourse studies do not isolate themselves from the linguistic context of the language used in legal texts. Thus, there is often a connection between language and legal texts; a connection in the sense that various legal texts, such as contracts, legislation and regulations, related to national and international jurisdictions, have been addressed not only from a legal angle, but also from a purely linguistic perspective. This shows the relevance of the different linguistic levels of analysis, such as the semantic, the pragmatic and the syntactic in the interpretation of legal texts.

\section{Law and Language: A Reciprocal Relationship}

Language is closely related to law, and the language of law, either spoken or written, constitutes various linguistic concepts that are worthy of linguistic research. This relationship has been the focus of many studies [29, 30]. In courtrooms, many laws are presented to defend or accuse. These laws are presented in an oral interaction that operates in a contextual environment of legal discourse. The interpretation of such laws depends to a high degree to the way language expressing these laws encodes ideology. The ability of discourse participants to perceive what beyond the mere linguistic expressions of laws, the way they are delivered in 
courtrooms, and the pragma-semantic meanings these linguistic expression convey makes discourse participants linguistically acquainted with enough information relevant to provide a proper interpretation for what is being communicated.

\section{Courtroom Discourse}

Courtroom discourse is a type of discourse delivered within the context of the courts of law. This type of discourse is often presented in a spoken form and is completely different from the type of discourse delivered in everyday interaction [31]. It depends on oral interaction between discourse participants to defend or challenge a specific argument in a particular way. This process of defense is largely based on the use of language, which in turn manifests itself either persuasively or manipulatively. The concepts of persuasiveness in courtroom discourse are determined by the extent to which speakers use language, as well as the readiness of the addressees to accept what is being communicated quite willingly.

Crucially, the function of language in courtroom discourse is not primarily linguistic; however, it is to defend the restoration of social order when it breaks down. This, of course, is delivered within a linguistic framework that facilitates the task of speakers and allows the realization of their desires so easily [32]. Obviously, courtroom discourse is characterized by the imbalances in power relations among discourse participants. Thus, there are two types of power here: a supreme power practiced by judges and another form of power derived from a background knowledge pertaining to lawyers' schemata concerning law. These types of power are exercised from one party over another in order to achieve specific purposes that serve the speaker. Importantly, in most cases, the notion that one party (speaker) is superior over another is ultimately based on the dexterous use of language [33].

\section{E. Critical Discourse Analysis}

Critical Discourse Analysis (CDA) perceives language as a carrier of ideological purposes. It addresses issues of power and ideology and shows the way language reflects power, control and discrimination among discourse participants [34]. This theory (i.e. critical discourse analysis) attempts to uncover the hidden relations of power in discourse in general and in courtrooms in particular. CDA is described as critical since it criticizes the way language can be biased towards specific ideological assumptions of its users [35]. It exposes the hidden ideologies and offers useful insights towards the understanding of the use of language in different types of discourse. van Dijk [36] considers CDA as a type of analytical research which is concerned with the ways through which power, dominance and inequality are produced, reproduced and exercised in text and talk within the different social and political contexts. Fairclough and Wodak [37] also postulate that CDA considers discourse as a form of social practice and takes consideration of the context of language use to be crucial to discourse. As such CDA focuses on the way language is used to produce control and exercise power in discourse, either spoken or written.
One intrinsic characteristic of CDA is its analytical ability to discover meaning beyond the superficial linguistic expressions of discourse. In this regard, Fairclough [38] argues that CDA has the capacity to explore obscure discursive relationships of causality and determination between two main elements in discourse: the discursive practices and the wider social and cultural structures, relations and processes. As such, CDA's theoretical and analytical agenda allows critical analysts to investigate the way such discursive practices and texts are loaded with different relations of ideology and power. CDA aims to describe, explain and interpret the relationship between discursive practices, social practices, and social structures [1]. In courtroom discourse, such relationships are clearly represented by discourse participants, be they judges, lawyers, witnesses, or otherwise [39]. CDA, therefore, attempts to uncover hidden ideologies in discourse practices and beyond. That is, it scrutinizes to analytically connect between the micro structures of discourse, which focuses on the linguistic devices used in texts and talks, and the macro structures, manifested in the analysis of the context of situation. This analytical connection operates effectively in legal settings, wherein a connection between the linguistic expressions and their contextual environment is highly indicative.

\section{F. Discourse and Persuasion}

Persuasion has been tackled by many linguists and sociolinguists [40, 41, 42]. Whateley [43] perceives persuasion as a science which constitutes the ability to use proper arguments to prove what one wants to communicate and achieve. Bryant [44] clarifies that persuasion is a process of subjugating specific ideas to different people and different people to specific ideas. For Lakoff [40], persuasion is an intentionally-based process that aims to reshape the behaviors of others by means of specific communicative means. Jowett and O' Donnell [41] consider persuasion as an interactive process of communication in which a speaker attempts intentionally to influence the beliefs and attitudes of receivers.

To Pardo [45], persuasion appears to be a linguisticallybased phenomenon used by one person to convince another of something. The different definitions of persuasion emphasize that it is a communicative process whereby speakers try to adjust, change, and influence others' attitudes to suit their own advantages. This perceives the study of persuasion as relevant to legal discourse and courtroom interaction. Persuasion is necessarily linked to power and therefore it always entails some degree of it. For [45], the point at which persuasion becomes manipulation or coercion depends on the extent to which power is exercised in discourse. In courtroom settings, this power can be exercised both persuasively and manipulatively in order to influence the attitude of recipients so as for them to adopt the speakers' point of view. Lawyers, thus, are supposed to use language in the opening statements in order to persuade the court of their client's position. 


\section{MethodologY}

This part is dedicated to presenting the process of data collection, data description, the rationale of the study and the framework of data analysis.

\section{A. Data}

The data used in the analysis of this paper consists of the two opening statements of Zacarias Moussaoui trial, a French citizen of Moroccan descent who was convicted of being involved in the terrorist attacks on the World Trade Center on September 11, 2001. Moussaoui's trial was located in the United States District Court, the Eastern District of Virginia, and dated March 6, 2006. The first opening statement is of U.S. Attorney Robert Spencer in the Moussaoui trial, which consists of 26 pages and counts nearly 6411 words. The second is of defense attorney Edward MacMahon, which consists of 31 pages and counts nearly 7571 words. The collected data is available at https://famous-trials.com/ moussaoui/1830-moussaouiexcerpts. Table I offers a description of the selected data.

TABLE I. DATA DESCRIPTION

\begin{tabular}{|l|l|l|}
\hline Description & $\begin{array}{l}\text { Opening Statement } \\
\text { of US Government }\end{array}$ & $\begin{array}{l}\text { Opening Statement } \\
\text { of Defense }\end{array}$ \\
\hline Attorney (speaker) & Robert Spencer & Edward MacMahon \\
\hline Number of Pages & 26 & 31 \\
\hline Number of Words & 6411 & 7571 \\
\hline Number of lines & 642 & 754 \\
\hline
\end{tabular}

The rationale constituting the selection of this trial in particular is due to three reasons. First, this case (i.e., Moussaoui trial) represents one part of the most effective event that reshapes world opinions in general and the American one in particular in terms of the image of Muslims and Islam. Second, the terrorist attacks on the World Trade Center directed the world accusation fingers to Al Qaeda and Osama bin Laden, the two symbols of terrorism against the West in the then time. Third, the selected trial reflects a type of legal discourse in a courtroom setting that shows the manner through which persuasion tactics are linguistically employed to achieve specific purposes of language users.

\section{B. Opening Statements}

Unlike the other elements in courtroom legal activities, opening statements are allowed to be delivered without any intervening activities from the court. That is, attorneys have the chance to expose the guidelines of their defense without interruption. This uninterrupted freedom of speech delivery facilitates their task to deliver their arguments persuasively. Johnson [46] emphasizes this characteristic by arguing that they represent the first opportunity to communicate persuasively and argumentatively with the jury without interruption. Through opening statements, attorneys can present their evidences concerning a case in hand. They are attempts to persuade the judge to issue a favorable verdict. According to Bradshaw [47], an opening statement should have a beginning, middle and an end. In other words, it should have an introduction, a body and a conclusion, through which the story and the theory of the case, its context of situation, evidences and counter evidences are supposed to deliver persuasively to win a positive legal stance $[48,49]$. Thus, the effectiveness of opening statements is measured by the lawyer's ability to persuade the judge to adopt a situation that benefits the defendant.

\section{Framework of Data Analysis}

Certain persuasive strategies used in the selected trial by the attorneys will be covered in the part of the analysis. These include the following: questioning, repetition, emotive language, and justification.

1) Questioning: within courtrooms, the act of questioning is one of the best ways of extracting information needed, either from the convicted person or the witnesses. This type of extracted information functions to persuade the judge of the case as a whole and thus enables him to give the final verdict. Questions in courtroom discourse may be in a form of yes/no questions, wh-questions, or rhetorical questions [50].

2) Repetition: This strategy depends on repeating certain words or ideas to achieve specific purposes on the part of the addressees. Brembeck and Howell [51] argue that repetition functions to attract attention to an idea or argument for some ideological purposes. They maintain that repetition is very important in communicating and emphasizing ideas among participants which, in turn, is essential in the process of persuasion.

3) Justification: Legal representatives always manipulate certain tactics of justifications in order to convince their participants of their arguments. van Dijk [52] states that justification is required in interaction between participants to legitimize their arguments. This strategy is employed in the selected data by the legal representatives to manipulate their recipients into submission to their arguments.

4) Emotive language: Using emotive language is another tool legal representatives use to affect their participants (the Jury, the Judge). Crucially, addressing the emotions of the recipients by employing words that may possibly develop and stimulate their potential is indicative in the production of a legal persuasive discourse [38].

\section{ANALYSIS AND RESULTS}

\section{A. Questioning}

In the two opening statements selected for study in this paper, questioning represents a fundamental element in Moussaoui's trial. In their opening statements, both defense attorney Edward MacMahon and the U.S. attorney Robert Spencer make use of this strategy. Regardless the fact that the defense attorney uses questioning (13 occurrences) more that his counterpart (4 occurrences), but all employed questions play a pivotal role in the process of persuasion within the court. Both attorneys utilize questions in their opening statements metalinguistically as is shown in the following selected extracts from the defense attorney Edward MacMahon: 
1) And who are we? We're a nation that's governed by laws and the Constitution. We try to provide equal justice to everyone. (Moussaoui Trial 'henceforth MT., [53], my emphasis).

2) So whatever role the government may say that Moussaoui played in the attacks, it was obviously so inconsequential that the attacks went forward in his absence and entirely without his participation. How? Because the evidence will show that Moussaoui wasn't part of the plot and was ignorant of its details. (MT., [53], my emphasis).

3) Khallad, our government says in e-mails that you will see in this case, was a major league killer. Did alarm bells go off? Did the government launch a massive manhunt for Khallad's lieutenants in the United States? You know the answer. (MT., [53], my emphasis).

4) Has the government ever heard of Airman Flight School before, ladies and gentlemen? Before 9/11, you will learn that Airman Flight School had hosted other al Qaeda members as flight students. Our government knew all of this before September $11^{\text {th }}$. (MT., [53], my emphasis).

The above extracts 1, 2, 3 and 4 display a dexterous use of metalinguistic questions; two of them have been initiated by the interrogative operators who and how, whereas the other two questions are in the yes/no form communicated by the auxiliaries did and has. Significantly, in all their semantic interrogative forms, the four questions above have a metalinguistic pragmatic function beyond their surface semantic directivity. That is, the four questions do not seek an answer, or prospect any response from recipients. However, they are employed to confirm a piece of information and to stimulate a cognitive work towards a specific argument. In 1 and 2 above, the metalinguistic questions are followed by their answer in an attempt to convey the meaning that the United States of America is a country of justice, in a reference that stimulate the fixed rules of the country so as to sympathize with Moussaoui (in 1), and that the defense attorney have evidences supporting Moussaoui's situation in the trial. Likewise, the answer of the metalinguistic question in 3 you know the answer aims to activate the jury as well as the audiences' thinking so as to ask themselves the same question and to seek the answer. Here, the answer of 3 carries the inferable meaning that facts and evidences of Moussaoui's innocence is apparent to everyone. This inferably pragmatic interpretation is also emphasized by the answer of 4 our government knew all of this before September $11^{\text {th }}$. Crucially, launching these questions, together with their immediately subsequent answer raises the possibility of persuasiveness on the part of the addressees. Consider Table II.

TABLE II. FREQUENCY ANALYSIS OF QUESTIONS USED to PERSUADE IN DEFENSE ATTORNEY OPENING STATEMENT

\begin{tabular}{|l|l|l|l|l|}
\hline \multicolumn{5}{|l|}{ Questioning } \\
\hline Opening Statement of Defense Attorney Edward MacMahon \\
\hline Type of question & $\begin{array}{l}\text { W-h } \\
\text { questions }\end{array}$ & $\begin{array}{l}\text { Yes/no } \\
\text { questions }\end{array}$ & $\begin{array}{l}\text { Rhetorical } \\
\text { questions }\end{array}$ & Total \\
\hline Frequency & 6 & 5 & 2 & 13 \\
\hline $\begin{array}{l}\text { Indicative } \\
\text { Occurrences }\end{array}$ & 6 & 4 & 2 & 12 \\
\hline
\end{tabular}

In a similar vein, the U.S. attorney Robert Spencer employs metalinguistic questions in his opening statement:

Before 9/11, anyone selected by the CAAPS system couldn't check their bag on to a plane until they themselves boarded the plane. Why? Because the FAA before 9/11 was concerned about people smuggling explosives in checked luggage onto planes. (MT., [53], my emphasis).

Spencer does not expect an answer. He asks his question and follows it with the answer. Here, he tries to highlight Moussaoui's accusation and to dissociate the U.S government from responsibility. Spencer's metalinguistic question then targets one meaning: the United States of America does not bear any responsibilities for the September 11th attacks, as it has taken all safety and security measures that were followed then. Courtroom questioning, in light of the analysis in this paper, are not intended to extract information, as is the case for interrogatives in any discourse settings. However, they are employed to communicate information, to stimulate a cognitive work and to confirm an argument. Consider Table III.

TABLE III. FREQUENCY ANALYSIS OF QUESTIONS USED TO PERSUADE IN U.S. ATTORNEY OPENING STATEMENT

\begin{tabular}{|l|l|l|l|l|}
\hline \multicolumn{5}{|l|}{ Questioning } \\
\hline \multicolumn{5}{|l|}{ Opening Statement of U. S. Attorney Robert Spencer } \\
\hline $\begin{array}{l}\text { Type of } \\
\text { question }\end{array}$ & $\begin{array}{l}\text { W-h } \\
\text { questions }\end{array}$ & $\begin{array}{l}\text { Yes/no } \\
\text { questions }\end{array}$ & $\begin{array}{l}\text { Rhetorical } \\
\text { questions }\end{array}$ & Total \\
\hline Frequency & 2 & 1 & 1 & 4 \\
\hline $\begin{array}{l}\text { Indicative } \\
\text { Occurrences }\end{array}$ & 1 & 0 & 0 & 1 \\
\hline
\end{tabular}

\section{B. Repetition}

Repetition is a critical discourse strategy used by speakers to affect a persuasive change in the attitudes of recipients. According to [51], repetition serves to clarify and to hold attention to an idea. This effect becomes more effective when certain repetitive expressions are recurrently used in the same speech/text. Repetition may appear in two forms: "either by using the same words or by stating the same idea in different words" [51]. In the selected data, repetition is employed in the two opening statements. See the following extract:

1) You can't judge him to get revenge for 9/11. You can't make him some substitute for Osama bin Laden. And you can't make him a scapegoat for what government officials did not do. (MT., [53], my emphasis)

The above words are said by the defense attorney towards the end of his opening statement. The repetitive expression you can't + infinitive emphasizes the function of language in communicating information. These expressions, for Letteri [54], are called "anaphoric expressions" and means the repetition of a word or phrase at the beginning of consecutive clauses or sentences. When repetition is employed, it aims at emphasizing the specific ideas or words that are repeated in discourse. As such, by using repetition, attorneys tend to effectively persuade their audiences. In fact, language has a variety of functions, but when it comes to confirmation of information, its significance is measured by what is repeated 
and the reason why this repetition takes place. As indicated in the above extract, repetition carries a pragmatic function, as it aims to confirm the specific meaning of innocence on the part of Moussaoui. This correlates with Pridham's argument [55] that speakers often repeat their arguments more than one time in order to ensure cooperation and full understanding. Pridham clarifies that repetition enables the speakers to check and then to confirm what has been said. Repetition, here, is employed to state the position of the defense attorney so as to help ensure comprehension of what he has been said and meant. Thus, repetition is very important in communicating and emphasizing ideas among participants which, in turn, is essential in the process of persuasion.

Another example of repetition can be found in the following extract from the opening statement of the U.S. Attorney:

2) On that day, September 11th, 2001, Moussaoui was a member of al Qaeda. On that day Moussaoui was part of the plot to hijack planes and crash them into U.S. buildings to kill as many U.S. Americans as possible. Moussaoui trained with al Qaeda as part of the plot. Moussaoui traveled to the U.S. as part of the plot. Moussaoui took flight training as part of the plot. Moussaoui purchased short-bladed knives, all part of the plot, all financed by al Qaeda as part of the plot. He was in the thick of it. (MT., [53], my emphasis).

As indicated in the above extract, repetition is utilized to emphasize an idea and to support an argument. The repetition of the prepositional phrase on that day functions to bring back the picture of what happened to the court, as well as to the addressees' minds. Also indicative is the repetition of the proper noun Moussaoui, which tends to cast emphasis on the identity of the person who is responsible for the attack. The use of the past tense that follows also aims to communicate actions verification and completeness. Repetition, here, is an important device because it allows the speaker to place emphasis on things he chooses as significant. It also tells the audience that the words being used are central enough to be repeated, and lets them know when to pay special attention to the language.

On the word level, certain words are used repeatedly in the two opening statements to carry specific meanings. For example, the lexis terrorist, kill, justice, attack, destruction, etc. with their different derivatives, are repeated in the two opening statements, as is clarified in Table IV.

As indicated in Table IV, specific words are used in the two opening statements to communicate particular meanings that aim to affect a persuasive discourse on the part of audiences. Words, such as kill, terrorist, attack, killers display high frequencies in the two statements; however, each attorney uses them for a goal contradictory to the other party. This contradictory objective is manifested in the discrepancy in the frequency of the same words used in each statement. That is, the US representative tries to persuade the court that Moussaoui is completely guilty, whereas the defense attorney attempts to prove the opposite: Moussaoui's innocence. Also indicative is the use of the proper name Moussaoui in the two statements, as well as the phrase September $11^{\text {th }}$. Again each usage has its target that serves his intention.

TABLE IV. FREQUENCY OF REPETITIVE INDICATIVE WORDS

\begin{tabular}{|l|l|l|}
\hline \multicolumn{2}{|l|}{ Repetition } & Frequency \\
\hline Word & $\begin{array}{l}\text { Opening Statement of U. S. } \\
\text { Attorney Robert Spencer }\end{array}$ & $\begin{array}{l}\text { Opening Statement of } \\
\text { Defense Attorney Edward } \\
\text { MacMahon }\end{array}$ \\
\hline Moussaoui & 104 & 97 \\
\hline Kill & 25 & 4 \\
\hline Terrorist & 15 & 5 \\
\hline Attack & 5 & 39 \\
\hline Terrorism & 2 & 4 \\
\hline Killers & 4 & 3 \\
\hline Terror & 2 & 10 \\
\hline Horror & 1 & 1 \\
\hline September $11^{\text {th }}$ & 22 & 31 \\
\hline Destruction & 2 & 0 \\
\hline Destroy & 1 & 0 \\
\hline Justice & 0 & 3 \\
\hline Slaughtered & 1 & 0 \\
\hline
\end{tabular}

Further, other words in company are repeated in the two opening statements to carry ideological significance to the thematic and persuasive message intended beyond the two statements. Consider Table V.

TABLE V. FREQUENCY OF INDICATIVE WORDS IN COMPANY

\begin{tabular}{|l|l|l|}
\hline Repetition & Frequency \\
\hline Word in Company & $\begin{array}{l}\text { Opening Statement of } \\
\text { U. S. Attorney } \\
\text { Robert Spencer }\end{array}$ & $\begin{array}{l}\text { Opening Statement of } \\
\text { Defense Attorney } \\
\text { Edward MacMahon }\end{array}$ \\
\hline Your honor & 2 & 2 \\
\hline Muslim fundamentalists & 1 & 16 \\
\hline Innocent Americans & 2 & 0 \\
\hline Civilian personnel & 2 & 0 \\
\hline Civilian people & 1 & 0 \\
\hline Cold blood & 1 & 0 \\
\hline Cold-blooded killers & 1 & 0 \\
\hline Al Qaeda member & 19 & 14 \\
\hline Al Qaeda associate & 12 & 9 \\
\hline
\end{tabular}

Table V shows some words in company with others, that is, in their contextual environment. This functions to reveal the ideological persuasive significance of these words. Thus, the use of the collocation your honor by the two attorneys is noticed, which indicates a commitment to particular terms of address in courtrooms. Also, the word Muslim is accompanied by fundamentalists to convey further terrorist meanings. Furthermore, the combination of Innocent, Civilian, and $\mathrm{Al}$ Qaeda to American, personnel, people, member, and associate, respectively, is highly indicative in the process of persuasion. 


\section{Justification}

Attorneys always manipulate certain tactics of justification in order to distance their legal clients from being blamed for any mischief. This strategy is dexterously employed in the selected data, as is shown in the following extracts:

1) Mr. Moussaoui introduced himself to you by proclaiming that he was al Qaeda and that we were all Americans. And on this point, and it may be the only one, I wholeheartedly agree with him. We all know that al Qaeda is a fanatic Islamic-based terror group, and we all know that their favorite weapon is suicide terrorism. Now, what we call suicide, they call martyrdom. And martyrdom is something special to an al Qaeda member. It is just what they yearn for. They live so that they can die. (MT., [53], my emphasis).

The above quote represents one of the most effective justifications used in the two opening statements under investigation. The defendant's lawyer has tried to blame a systematic ideology of a terrorist group (i.e., Al Qaeda). He is trying to prove that Moussaoui's problem lies in his involvement in an ideology-based extremist movement, which portrays him as a martyr who attains the highest degrees in heaven as a reward of any terrorist attack what we call suicide, they call martyrdom. Here lies the difference in ideology between the Western culture represented in the United States of America, the subject of the terrorist attack, and the Islamic countries from the point of view of the lawyer. This justification aims to transform the issue from a personal issue to an ideological one. The inferable meaning here is that Moussaoui is a victim of a systematic brainwashing process by Al Qaeda.

TABLE VI. FREQUENCY OF INDICATIVE WORDS USED TO JUSTIFY

\begin{tabular}{|l|l|l|}
\hline Justification & Frequency \\
\hline Word & $\begin{array}{l}\text { Opening Statement } \\
\text { of U. S. Attorney } \\
\text { Robert Spencer }\end{array}$ & $\begin{array}{l}\text { Opening Statement of } \\
\text { Defense Attorney Edward } \\
\text { MacMahon }\end{array}$ \\
\hline Martyrdom & 0 & 5 \\
\hline Martyr & 0 & 1 \\
\hline Al Qaeda & 31 & 23 \\
\hline Constitution & 0 & 3 \\
\hline Victims & 2 & 2 \\
\hline Conspiracy & 1 & 0 \\
\hline Conspirators & 5 & 0 \\
\hline
\end{tabular}

Table VI demonstrates a number of words and their frequencies in the two opening statements. These words are employed to justify the situation of each party, either on the part of the US Attorney or the defense representative.

\section{Using Emotive Language}

Addressing the emotions of the recipients by employing words that may possibly develop and stimulate their potential is another strategy that can produce a persuasive discourse [56]. In light of this paper, certain linguistic expressions are used by the U.S. attorney to address the emotions of his audience. See the following extracts that are delivered at the very beginning of his opening statement:

1) September 11th, 2001 dawned clear, crisp and blue in the northeast United States. In lower Manhattan in the Twin Towers of the World Trade Center, workers sat down at their desks tending to e-mail and phone messages from the previous days. In the Pentagon in Arlington, Virginia, military and civilian personnel sat in briefings, were focused on their paperwork. In those clear blue skies over New York, over Virginia, and over Pennsylvania, in two American Airlines jets and in two United Airlines jets, weary travelers sipped their coffee and read their morning papers as flight attendants made their first rounds. (MT., [53], my emphasis).

2) But a day that started so normally and with such promise, soon became a day of abject horror. By morning's end, 2,972 people were slaughtered in cold blood. And that clear, blue sky became clouded with dark smoke that rose from the Trade Towers of New York, from the Pentagon in Virginia, and from a field in rural Pennsylvania. And within a few hours out of that clear, blue sky came terror, pain, misery, and death, and those 2,972 never again saw their loved ones, never again gave their kids a goodnight kiss. That day, September 11th, 2001, became a defining moment, not just for 2,972 families, but for a generation. (MT., [53], my emphasis).

The above extracts represent a clear example of employing emotive language to stimulate the sympathy of recipients. The two extracts communicate two contradictory pictures of the situation immediately before and after 11 September attacks. The U.S. Attorney representative tries to stimulate his audiences emotionally in order to influence their attitude and make them respond in a way that serves his purposes. In fact, delineating the situation before and after the terrorist attacks brings to the minds of listeners the atrocities committed against humanity in such a day. Discursively, addressing the emotions of discourse recipients always targets a shift in their attitudes towards the issue addressed [57]. Textually, the two extracts are structured around a semantically oppositional discourse, wherein some expressions, such as dawned clear, crisp and blue, civilian personnel, clear blue skies, and weary travelers in extract (1) are semantically counterparted with $a$ day of abject horror, people were slaughtered in cold blood, clouded with dark smoke, out of that clear, blue sky came terror, pain, misery, and death. These expressions serve to motivate the emotions of recipients, which in turn aims to make them adopt only one attitude that serves the goals and allegations of the U.S. representative in the case. 
TABLE VII. FREQUENCY OF INDICATIVE EXPRESSIONS USED TO AFFECT EMOTIONS

\begin{tabular}{|c|c|c|c|}
\hline \multicolumn{4}{|l|}{ Emotive Language } \\
\hline \multicolumn{2}{|l|}{$\begin{array}{l}\text { Opening Statement of U. S. } \\
\text { Attorney Robert Spencer }\end{array}$} & \multicolumn{2}{|l|}{$\begin{array}{l}\text { Opening Statement of Defense } \\
\text { Attorney Edward MacMahon }\end{array}$} \\
\hline Expression & Freq. & Expression & Freq. \\
\hline $\begin{array}{l}\text { September 11th, } 2001 \\
\text { dawned clear }\end{array}$ & 1 & $\begin{array}{l}\text { This case poses the ultimate } \\
\text { test to our legal system }\end{array}$ & 1 \\
\hline $\begin{array}{l}\text { Crisp and blue in the } \\
\text { northeast United States }\end{array}$ & 2 & $\begin{array}{l}\text { Our justice system can only } \\
\text { be judged by how it treats } \\
\text { the poorest }\end{array}$ & 1 \\
\hline $\begin{array}{l}\text { Civilian personnel sat in } \\
\text { briefings, were focused on } \\
\text { their paperwork. }\end{array}$ & 2 & $\begin{array}{l}\text { The most despicable person } \\
\text { who is charged with the } \\
\text { most heinous of crimes }\end{array}$ & 1 \\
\hline $\begin{array}{l}\text { In those clear blue skies } \\
\text { over New York }\end{array}$ & 1 & $\begin{array}{l}\text { The prison jumpsuit that he } \\
\text { will wear for the rest of his } \\
\text { life }\end{array}$ & 1 \\
\hline $\begin{array}{l}\text { Weary travelers sipped } \\
\text { their coffee and read } \\
\text { their morning papers }\end{array}$ & 1 & $\begin{array}{l}\text { We're a nation that's } \\
\text { governed by laws and the } \\
\text { Constitution }\end{array}$ & 1 \\
\hline $\begin{array}{l}\text { Soon became a day of } \\
\text { abject horror }\end{array}$ & 1 & $\begin{array}{l}\text { We try to provide equal } \\
\text { justice to everyone }\end{array}$ & 1 \\
\hline $\begin{array}{l}\text { People were slaughtered } \\
\text { people were slaughtered } \\
\text { in cold blood }\end{array}$ & 2 & $\begin{array}{l}\text { Our Constitution guarantees } \\
\text { to all defendants the right to } \\
\text { a jury trial }\end{array}$ & 1 \\
\hline $\begin{array}{l}\text { Sky was clouded with } \\
\text { dark smoke }\end{array}$ & 1 & $\begin{array}{l}\text { A check against the abuse of } \\
\text { government power }\end{array}$ & 1 \\
\hline $\begin{array}{l}\text { Out of that clear, blue sky } \\
\text { came terror, pain, misery, } \\
\text { and death. }\end{array}$ & 1 & $\begin{array}{l}\text { But he has not admitted any } \\
\text { involvement in the } \\
\text { September } 11 \text { th attacks }\end{array}$ & 1 \\
\hline
\end{tabular}

Table VII clarifies a number of expressions used to affect the emotions of both the audience and the court towards the addressed case. Each part tries to address the emotions of the recipients by employing expressions that may possibly develop and stimulate their potential towards action, which in turn influences a persuasive legal discourse.

\section{CONCLUSION}

This paper used a computer-aided text analysis manifested in a frequency distribution analysis and the keyword in context analysis, together with critical discourse analysis to present a linguistic investigation of the language of persuasion in courtroom discourse. This is conducted by shedding a computational linguistic light on certain strategies of persuasion used in the selected data. These strategies include questioning, repetition, justification and addressing emotive language. The four CDA strategies show the extent to which language is used to produce a persuasive discourse, and emphasize the assumption that CDA is a deconstructive approach to the analysis of power and ideology in discourse [58]. The paper also demonstrated that courtroom discourse is a type of institutional discourse characterized by inequality in power relations among discourse participants. This type of discourse is goal oriented; that is, it always targets specific purposes beyond the discursive practices delivered in court settings. The four devices are intentionally utilized by discourse participants to guarantee the realization of their intended purposes and the acceptance of their arguments in a particular way.

The analysis further showed the relevance of applying a computer-assisted analysis and a critical discourse analysis to the study of courtroom discourse. This in turn emphasizes the relationship between critical discourse analysis, as a multidisciplinary approach, the language of law, and computer applications in corpus linguistics. Finally, for future research, this paper recommends further linguistic studies on other courtroom popular cases (e.g., former Iraqi president Saddam Hussien's trial). This could reveal similar or different findings than what this study provides in terms of the CDA strategies used among discourse participants and the way these linguistic devices operate in legal settings and revealed by computational tools.

\section{ACKNOWLEDGMENT}

This publication was supported by the Deanship of Scientific Research at Prince Sattam bin Abdulaziz University under the Research Project No. 2020/02/12137.

\section{REFERENCES}

[1] N. Fairclough, Language and power (2nd ed.). London and New York: Longman, 2013.

[2] M. Coulthard, and A. Johnson, An introduction to forensic linguistics. London: Routledge. 2007.

[3] M. L. Heyden, J. Oehmichen,S. Nichting, and H. W. Volberda, "Board background heterogene-ity and exploration-exploitation: The role of the institu-tionally adopted board model,".Global Strategy Journal,5(2), 2015, 154-176.

[4] S. Hockey, A Guide to Computer Applications in the Humanities. London: The Johns Hopkins University Press, 1980.

[5] G. Kennedy, An Introduction to Corpus Linguistics. London \& New York: Longman, 1998.

[6] R. P. Weber, Basic content analysis. NewburyPark, CA: Sage, 1990.

[7] D. Krieger, "Corpus linguistics: What it is and how it can be applied to teaching," The Internet TESL Journal, Vol. IX, No. 3, 2003, pp. 123141.

[8] D. Wiechmann, and S. Fuhs, "Concordancing software," Corpus Linguistics and Linguistic Theory, Vol. 2, No. 2, 2006, pp.2006, pp. 107-127.

[9] J. Flowerdew, "Concordancing as a tool in course design," System, vol. 21, no. 2, 1993, pp. 231-244

[10] F. Yavus, "The use of concordancing programs in ELT," ProcediaSocial and Behavioral sciences, Vol. 116, pp. 2312-2315, 2014.

[11] C. D. Manning, "Probabilistic syntax," in R. Bod, J. Hay, and S. Jannedy, Eds., Probabilistic linguistics. Cambridge, MA: MIT Press, pp. 289-341, 2003.

[12] I. Pollach, " Taming textual data: The contributionof corpus linguistics to computer-aided text analysis," Organizational Research Methods, Vol. 15, No. 2, 2012, 263-287.

[13] A. Trosborg, Rhetorical strategies in legal language: Discourse analysis of statutes and contracts. Tübingen: Gunter Narr Verlag, 1997.

[14] P. M. Tiersma, Legal language. Chicago: University of Chicago Press, 1999.

[15] V. K. Bhatia, Analysing genre: Language use in professional settings. London: Longman, 1993.

[16] S. Harris, "Interrogation and evidence: Questioning sequences in courtroom discourse and police interviews," in C. Candlin, and S. Sarangi, Eds., Handbook of communication in organizations and professions. Berlin: De Gruyter, 2011, pp. 277-298.

[17] G. Stygall, "Discourse in the US courtroom," in P. Tiersma, and L. Solan, Eds., The Oxford handbook of language and law. Oxford: Oxford University Press, 2012, pp. 369-380. 
[18] J. Engberg, "Word meaning and the problem of a globalized legal order," in P. Tiersma, and L. M. Solan, Eds., Oxford handbook of language and law. Oxford: Oxford University Press, 2012, pp. 175-186.

[19] M. Gotti, and C. J. Williams, Eds., Legal discourse across languages and cultures. Bern: Peter Lang, 2010.

[20] V. K. Bhatia, "Interdiscursive colonization of arbitration practice," World Englishes, Vol. 30 , No. 1, 2011, 76-80.

[21] P. Tiersma, P., and L. M. Solan, Eds., The Oxford handbook of language and law. Oxford: Oxford University Press, 2012.

[22] C. Williams, and G. Tessuto, Eds., Language in the negotiation of justice: Contexts, issues and applications. Farnham: Ashgate, 2013.

[23] V. K. Bhatia, and M. Gotti, Eds., Arbitration discourse in Asia. Peter Lang: Bern, 2015.

[24] G. Tessuto, Ed., Constructing legal discourses and social practices: Issues and perspectives. Cambridge: Cambridge Scholars Publishing, 2016.

[25] V. K. Bhatia, G. Garzone, R. Salvi, G. Tessuto, and C. Williams, Eds., Language and law in professional discourse: Issues and perspectives. Newcastle upon Tyne: Cambridge Scholars Publishing, 2014.

[26] V. K. Bhatia, G. Garzone, R. Salvi, G. Tessuto, and C. Williams, Eds., Language and law in academic and professional settings. Analyses and applications. In Explorations in language and law 1, Novalogos: Roma, 2014.

[27] J. Bradac, "Language style on trial: Effects of "powerful" and "powerless" speech upon judgments of victims and villains," The Western Journal of Speech Communication, Vol. 45, 1981, pp. 327-341.

[28] G. Mtoesian, Law and the language of identity: Discourse in the William Kennedy Smith rape trial. Oxford: University Press, 2001.

[29] D. Eades, "I don't think it's an answer to the question: Silencing Aboriginal witness in court," Language in Language, Vol. 29, 2000, pp. 169-195.

[30] R. O. Farinde, Forensic linguistics: An introduction to the study of language and the law. Muenchen: Lincom Europa, 2009.

[31] M. Santos, A pragmalinguistic analysis of courtroom questions in a multilingual context. Retrieved from: http://www.tesionline.it/consult/ pdfpublicview.asp 8309/18309p.pdf, 2004.

[32] R. Mead, Courtroom discourse. Birmingham: University of Birmingham Printing Section, 1985.

[33] S. Hale, "The interpreter on trial: Pragmatics in court interpreting," in Carr et al, Eds., The critical link: Interpreters in the community. Philadelphia: John Benjamins, 1997, pp. 201-211.

[34] J. Blommaert, and C. Bulcaen, "Critical discourse analysis," Annual Review of Anthropology, Vol. 29, 2000, pp. 447-466.

[35] T. A. van Dijk, Discourse and knowledge: A sociocognitive approach. Cambridge University Press, 2014.

[36] T. A. van Dijk, "Discourse, ideology and context," Folia Linguistica, vol. xxx, No. 1(2), 2001, pp. 11-40, 2001.

[37] N. Fairclough, and R. Wodak, "Critical discourse analysis," in T. A. van Dijk, Ed., Discourse Studies: A Multidisciplinary Introduction, Vol. 2. Discourse as Social Interaction. London, UK: Sage Publications, 1997.

[38] N. Fairclough, Critical discourse analysis: The critical study of language. London, UK: Longman, 1995.
[39] A. Supardi, "A critical discourse analysis on language power and strategy used by jurists," US-China Foreign Language Journal,Vol. 8, No. 7, 2010, pp. 13-25.

[40] R. T. Lakoff, "Persuasive discourse and ordinary conversation, with examples from advertising," in D. Tannen, Ed., Analyzing discourse: Text and talk. Georgetown University Press, 1982, pp. 25-42.

[41] G. Jowett, and V. O'Donnell, Propaganda and persuasion ( $2^{\text {nd }}$ ed.). London and Newbury Park: Sage, 1992.

[42] J. Charteris-Black, Politicians and rhetoric. The persuasive power of metaphor. Palrave Macmillan, 2005.

[43] R. Whately, Elements of rhetoric. Cardandale: Southern Illinios Press, 1963.

[44] D. C. Bryant, "Rhetoric: Function and its scope," in D. Ehninger, Ed., Contemporary rhetoric. Glenview, IL: Scott Foresman, 1972, pp. 15-37.

[45] M. L. Pardo, "Linguistic persuasion as an essential factor in current democracies: Critical analysis of the globalization discourse in Argentina at the turn and at the end of the century," Discourse \& Society, Vol. 12 , No. 1, 2001, pp. 91-118.

[46] J. A. Johnson, "Persuasion in opening statement - generating interest in a convincing manner," Michigan Bar Journal, Vol. 90, No. 1, 2011, pp. 42-45.

[47] G. Bradshaw, "Structure of the opening statement,". E-Journal, Information, News, \& Events, Vol. 3, No. 5, 2009. Retrieved on May13, 2020 from http://www.litcounsel.org/080409/bradshaw.htm

[48] S. Lubet, Modern trial advocacy: Analysis and practice. USA: National Institute for Trial Advocacy, 2004.

[49] T. Mauet, Trials: Strategy, skills, and the power of persuasion. USA: Aspen Publisher, Inc, 2005.

[50] M. A. Fărcaşiu, "Language in the courtroom: a comparative study of American and Romanian criminal trials," International Journal of Speech Language and the Law, Vol. 19, No. 1, 2012, pp. 109-112.

[51] L. W. Brembeck, and S. W. Howell, Persuasion: A means of social control. Prentice-Hall, INC, 1952.

[52] T. A. van Dijk, "Principles of critical discourse analysis," Discourse \& Society, vol. 4, No. 2, pp. 249- 283, 1993.

[53] Moussaoui Trial, Famous Trials. Available at https://famoustrials.com/moussaoui, 2006.

[54] R. Letteri, A handbook of public speaking. Boston, USA: Allyn and Bacon, 2002.

[55] F. Pridham, The language of conversation. London and New York: Routledge, 2001.

[56] A. F. Khafaga, "Linguistic manipulation of political myth in Margaret Atwood's The Handmaid's Tale," International Journal of English Linguistics, Vol. 7, No. 3, 2017, pp. 189-200.

[57] A. F. Khafaga, "Linguistic representation of power in Edward Bond's Lear: A lexico-pragmatic approach to critical discourse analysis," International Journal of English Linguistics, Vol, 9, No. 6, 2019, pp. 404-420.

[58] A. F. Khafaga, "Discourse interpretation: A deconstructive readeroriented approach to critical discourse analysis," International Journal of Applied Linguistics and English Literature, Vol, 6, No., 2, 2017, pp. 138-146. 